\section{EDUCATION TOWARDS \\ ENTREPRENEURIAL CAREERS IN \\ A CZECH COLLEGE: \\ AN EMPIRICAL STUDY}

\begin{abstract}
The article presents the results of research into entrepreneurship education in economic and noneconomic study programmes of the College of Polytechnics Jihlava $(n=104)$. The College represents a regional public college of professional orientation in the Vysočina Region, where the business potential is relatively high. Significant differences in attitudes concerning entrepreneurship among students of economic and non-economic programmes have not been proven. As well the correlation between attitudes (interest in conducting business, having preconceptions to start a business and subjective evaluation of one's own ideas) and the students' knowledge of entrepreneurship was not significantly demonstrated. Despite these insignificant differences, there have been links in students' attitudes. Students of both programmes have a great interest in doing business even at the cost of having preconception to start a business. Above all, the high risk and uncertainty of business earnings are perceived very negatively. They also admit that they do not have enough knowledge and are thus afraid of starting a business, even though they have their own business ideas. Therefore, it is desirable to focus on new platforms for the development of entrepreneurship education and thus support the potential of students.
\end{abstract}

\section{KEYWORDS}

Entrepreneurship education, economic and non-economic study programmes, attitude towards business, business education platforms

\section{HOW TO CITE}

Berková K., Frendlovská D., Pospišil Závodný J., Vojáčková H., Kolářová D. (2020) ‘Education towards Entrepreneurial Careers in a Czech College: An Empirical Study', Journal on Efficiency and Responsibility in Education and Science, vol. 13, no. 1, pp. 1-9. http://dx.doi. org/10.7160/eriesj.2020.130101

\section{Kateřina Berková ${ }^{1 \rrbracket}$ \\ Dagmar Frendlovská ${ }^{1}$ \\ Jan Pospíšil Závodný ${ }^{1}$ \\ Hana Vojáčková2 \\ Dana Kolářová ${ }^{3}$ \\ ${ }^{1}$ Department of economic studies, \\ College of Polytechnics Jihlava, Czech \\ Republic}

${ }^{2}$ Department of technical studies,

College of Polytechnics Jihlava, Czech Republic

${ }^{3}$ Department of Economic Teaching Methodology, Faculty of Finance and Accounting, University of Economics, Prague, Czech Republic

katerina.berkova@vspj.cz

\section{Article history}

Received

April 28, 2019

Received in revised form

October 13, 2019

Accepted

December 15, 2019

Available on-line

March 31, 2020

Highlights

- The development of entrepreneurship education is important to support students' entrepreneurial potential.

- There are no differences in attitudes towards entrepreneurship among students in different programmes.

- Students' attitudes and knowledge about starting a business do not correlate.

\section{INTRODUCTION}

Some of the well-known and successful world entrepreneurs did not graduate from college. As an example, we can list names like Richard Branson, founder of Virgin Group, Steve Jobs, co-founder of Apple Inc., or Mark Zuckerberg, founder of Facebook. Many young people are trying to go along the same path today, but often without the expected success which was achieved by their famous precursors (Zhang, 2014). An exaggerated willingness to give up a college degree for the sake of business success could be caused by several reasons. First of all, it is given by the success stories of the mentioned entrepreneurs, and not just them. Many successful entrepreneurs argue that they did not need a college education for their success (Buenstorf, Nielsen and Timmermans, 2017). As another reason, the inborn and fixed personality traits of students with business intentions could be mentioned (Gartner, 1988). If the traits like willingness to take a risk, need for achievement or the locus of control and desire for autonomy, are important for the decision to become an entrepreneur on one hand (Cromie, 2000), on the other hand, those traits will also negatively interfere with the potential for successful college graduations (Parker, 2004). However, as a very serious reason, actual quality, structure and added value of entrepreneurial education programmes must be mentioned (Cho, 2017). 
For the universities, especially for those economically oriented, entrepreneurship is one of the main fields of research (Chen, 2013). Relatively strong orientation on entrepreneurship research in the Czech Republic is partly given historically since Czech born scientist Josef Alois Schumpeter started related research works in the 1930s (Schumpeter, 1934). Entrepreneurship is not just an economic or management discipline since it has been broadly examined in the point of view of several other disciplines including psychology, sociology, and anthropology (Simpeh, 2011). It can be assumed that universities are an inexhaustible source of important and valuable theoretical information relevant for successful entrepreneurship. But the question, whether they are able to transfer them effectively to the students, remains unanswered. Stress on the importance of entrepreneurship education is given worldwide (Lima et al., 2015). In this direction, it is not a coincidence, that the United Nations Conference on Trade and Development called entrepreneurship as an important item in promoting the development of countries (UNCTAD Secretariat, 2011). The issue of education as the development factor of students' entrepreneurial intentions should be examined at least from the two points of view. On one side, there is classical education related to the area of educational focus of the colleges. On the other side, special entrepreneurship education programmes should be mentioned (Fayolle, Gailly and Lassas-Clerc, 2006).

There are some pieces of evidence that college education has a significant negative effect on students' entrepreneurial intention, as well as on self-efficacy (Lima et al., 2015). It may seem that higher education is a barrier in chasing the entrepreneurship. In this case, however, it is rather about bad judgment. As statistics shows, 80 percent of new businesses will fail in its first 5 years (Zhang, 2014), the issue can have a positive explanation. In the Czech Republic, start-ups are developing more and more as a form of business support. It is about the support of start-ups. There were 2,100 start-ups at the end of 2017. Ministry of Industry and Trade has not published new data yet. Most of these businesses (70\%) are still in the early stages of business. The success rate of these new businesses is 10\% (Ministry of Industry and Trade, 2017). Education is giving the students the time to think and critically evaluate their business intentions. Thanks to their own sorting process, students are more conscious of what an entrepreneurial career is and what it would demand of them (Lima et al., 2015). Anyhow, the overall impacts of entrepreneurship education are positive for both the students as the society in whole (von Graevenitz, Harhoff and Weber, 2010).

If college education has a moderating impact on students' entrepreneurial intentions, it has almost no distinguishable impact on personality traits of the students (Lima et al., 2015). Actually, these are the most important factors in the development of students' entrepreneurship (Murugesan and Dominic, 2012). Previous research shows a strong link between the business creation and its success with numerous personality constructs, traits and characteristic (Rauch and Frese, 2007). One of the most frequently cited characteristics of entrepreneurs referring to a greater than average need for achievement is among the most frequently identified qualities (e.g. Rauch and Frese,
2007; Miner, 2000; Stewart and Roth, 2007). Interestingly, entrepreneurs are also often found to be highly motivated to obtain feedback on their performance (Rauch and Frese, 2000). Persons with entrepreneurial interests also enjoy interacting with other people, but they are not emotionally dependent on them (Decker, Calo and Weer, 2012). Naturally, others more common traits like a high level of goal-setting behaviour and perseverance (van Eeden, Louw, and Venter, 2005), placing greater value on autonomy, freedom, and independence (Rauch and Frese, 2007), or propensity to take moderate-level risks (Kreiser, Marino and Weaver, 2002) have been identified as characteristic of entrepreneurs. However, it is necessary to draw attention to the fact, that despite the high occurrence in the literature, the "Big Five" (McCrae and John, 1992) is not suitable for measuring entrepreneurial abilities (Rauch and Frese, 2000; Decker, Calo and Weer, 2012).

In contrast, some authors argued that though the personality traits play a crucial role by predisposing someone to become an entrepreneur, in fact, the entrepreneurial skills can be taught (Neck et al., 1999). However, this is again related to the quality and content of education. In general, it is possible to say that good education for entrepreneurship should be composed of such elements that can accentuate theories and principles of entrepreneurship in order to develop students' cognitive skills (Fiet, 2001). However, due to the expected necessity of reallife experiences, the practice-based approach is more important (Ireland et al., 2001).

Specific entrepreneurship education programmes can fulfil this necessity. Some studies (Fayolle, Gailly and LassasClerc, 2006; Hatten and Ruhland, 1995) suggest that special training programmes, teaching methods or even student training companies can have a strong measurable impact on the entrepreneurial intention of the students, but they have not a significant impact on students' perceived behavioural control. Thus, trying to create a definition of best education towards the entrepreneurship seems very complicated. Only general recommendations can be quoted. Entrepreneurship education should include educational areas such as general business knowledge, including market analysis and planning, pricing strategies, financial analysis, leadership, human resource management theory and other business theory and skills (Block and Stumpf, 1992). At the same time, students should be trained to make decisions in an uncertain environment, as well as on how to select and manage new businesses (Ronstadt, 1985). Important is also the finding that entrepreneurship education requires practical learning based on experience rather than traditional lecture methods (Lee et al., 2018). As a conclusion, it could be stated that entrepreneurship teaching is important to both a theoretical as well as a practical aspect of entrepreneurship (Anderson and Jack, 2008).

\section{Research Problem and Objective}

The aim of the study is to analyze the current state of entrepreneurship education at the College of Polytechnics Jihlava. The topic is chosen for its importance and with regard to the potential of the city of Jihlava and the Vysočina Region in the development of young people's entrepreneurship potential, which has not been used so much so far. The topic 
is so important that in the Vysočina Region it establishes the idea of developing start-ups as a tool to support young people's entrepreneurship. This reason has motivated researches for conducting the research, and thus this study, which is focused on the interest in entrepreneurship for the time being among students of economic and non-economic fields of the regional university, has developed. The selection of the institution was due to the condition of doing research at a practically oriented polytechnic institution providing more different fields of study. There are only two polytechnic colleges in the Czech Republic, namely in the Vysočina Region and the South Bohemian Region. The Vysočina Region was chosen for this research also because the researchers know very well the education system at the College of Polytechnics Jihlava, as they work there as teachers. Another reason for the selection was the potential of the Vysočina Region for the development of entrepreneurship. Conducting the research was also motivated by an international empirical study (Lima et al., 2015), which publishes the survey results of 25,000 respondents, concluding that interest in entrepreneurship is negatively correlated with tertiary education. Given the need to represent economic and non-economic programmes in the research sample, research was conducted across the college programmes. The research was conducted on the basis of a questionnaire to find out: (1) how the attitudes concerning entrepreneurship among students of economic and non-economic programmes differ; (2) what students' preconceptions of starting a business are and how they restrict them at the start. The relation between the interest in starting a business among students and their knowledge of starting a business is further explored. Following research hypotheses are the subject to verification:

- H1: The interest in entrepreneurship is higher for students of economic programmes than for students of non-economic programmes.

- H2: Preconceptions as a barrier for starting a business are perceived by students of economic programmes more than by students of non-economic programmes.
- H3: Economic programme students differ from noneconomic programme students by having a business idea and knowing exactly how to conduct business.

- H4: Students' attitudes concerning entrepreneurship and knowledge about conducting a business correlate.

The research represents an initial survey with the ambition of prospective data expansion and inter-university comparison of entrepreneurship education in the Czech Republic. The article provides empirically-based knowledge that is important for developing tools (teaching methods and platforms) to promote entrepreneurship during education.

\section{MATERIALS AND METHODS}

The research was conducted from October to November 2018 across the study programmes of the College of Polytechnics Jihlava. The survey was aimed at students who were involved in the project "Starting for Development of Students' Entrepreneurial Potential of the College of Polytechnics Jihlava". The project involved 104 students. All these students also participated in the research that is why the number of respondents was considered as a representative sample only to the project. There were students of the first to the third year of bachelor study programmes of the University of Polytechnics Jihlava (73 women and $31 \mathrm{men})$. These were mostly respondents from the Vysočina Region (75\%). All students of the College of Polytechnics Jihlava, both full-time and part-time, had the opportunity to enrol in the project concerning the start-up business. In 2018, approximately 2,200 students studied at the university (College of Polytechnics Jihlava, 2018). Considering that the number of students at the time of the research was approximately 2,200, there is a certain limit to the research in this respect. The structure of the research sample by the field of study is shown in Table 1.

The division of the sample according to the economic and non-

\begin{tabular}{|l|c|c|}
\hline \multicolumn{1}{|c|}{ Study programme } & Absolute frequency & Relative frequency (\%) \\
\hline Finance and Management & 30 & 28.8 \\
\hline Travel and Tourism & 32 & 30.8 \\
\hline Applied Computer Science & 11 & 10.6 \\
\hline Engineering for Industry & 7 & 6.7 \\
\hline Computer Systems & 5 & 4.8 \\
\hline General Nurse & 4 & 3.9 \\
\hline Clinical Social Worker & 15 & 14.4 \\
\hline Total & $\mathbf{1 0 4}$ & $\mathbf{1 0 0 . 0}$ \\
\hline
\end{tabular}

Table 1: Structure of Research Sample, 2018 (Source: Authors' Calculation)

economic fields corresponds to the representation of the study programmes at the college. The economic study programme is one of the dominant ones and is represented by the following fields: Finance and Management; Travel and Tourism. There are 62 respondents from the economic study programme in the research sample $(59.6 \%)$. Other study programmes are among the non-economic fields with a research sample of 42 respondents $(40.4 \%) .73 .1 \%$ of respondents are students interested in conducting business and $26.9 \%$ of respondents are students without a desire to conduct business. The first-year students involved 57 participants, the second-year students 24 participants and 23 students studied in the third year of bachelor's degree. Further, 53 students are enrolled in the full-time study programme and 41 students in part-time studies.

The analyzed data have the character of categorical and quantitative variables. The quantitative variables were data 
obtained from points from a test that was part of the questionnaire. Data were examined for two basic areas:

a) according to students' attitudes to entrepreneurship (categorical data were obtained from this part on the basis of students' evaluation using a scale; scaling contained 4 to 5 variations in this section, the higher the value, the stronger the interest or preconception to conduct business);

b) according to the relation between students' interest in entrepreneurship and their knowledge (from this part, quantitative data were obtained as a score from the test that was part of the survey).

The questioning method and test method were used for the data collection. The questionnaire which included a knowledge test was composed of three parts consisting of several questions:
- Students' attitudes concerning entrepreneurship (A. Interest in conducting business; B. Preconception to conducting business; C. Respondent has a business idea and knows or does not know how to implement it).

- Knowledge about starting a business (legislative processes for setting up a business, duties to a tax office, social insurance for an entrepreneur, bookkeeping, or tax records); it was a test that contained 7 questions. The questions were selected according to their importance for business practice.

- Factual data of respondents (sex, region, study programme).

The wording of questions and the knowledge test score are included in Table 2 .

\begin{tabular}{ll}
\multicolumn{1}{c}{ Question } & Score \\
\hline 1. Taking action to acquire a Trade Licence & 2 \\
\hline 2. Conditions for obtaining an unqualified notifiable trade & 2 \\
\hline 3. Registration to the tax office & 1 \\
\hline 4. Social insurance of an individual entrepreneur & 1 \\
\hline 5. Keeping records with an individual entrepreneur & 3 \\
\hline 6. Keeping records with a trading company & 1 \\
\hline 7. The amount of registered capital & 1 \\
\hline Total score & $\mathbf{1 1}$ \\
\hline
\end{tabular}

Table 2: Questions in Knowledge Test and Scores, 2018 (Source: Authors' Calculation)

The questions used were closed with 4 offered options. There were more correct answers. The performance of the test was evaluated according to the number of correct answers. The number of points assigned to each question reflected the number of correct answers, i.e. 1 correct answer $=1$ point, 2 correct answers $=2$ points, etc. Thus, the questions were differentiated according to the difficulty, as more correct answers meant the need to think about the question and have a higher knowledge of the issues. Selected questions that were part of the test are listed lower.

If a natural person operates as an individual entrepreneur, there are the following options for management evidence for which they may opt:
a) Tax records of income and expenses - application of actual expenditure
b) Tax records of income and expenses - application of flat- rate expenditure ( $\%$ of revenue)
c) Accounting (double-entry)
d) Simple accounting

In the case of unqualified trade, the entrepreneur must comply with the law:
a) Obtain an identity card.
b) Be of legal age.
c) Be impeccable.
d) Be professionally competent.

The questionnaire and test included in it had been subjected to a pilot test before main research started on a small sample of students $(n=8)$ who copied the features of the main research respondents. The questionnaire was then modified to increase its validity and reliability.

To verify the hypotheses, the data were processed and evaluated using the NCSS statistical software. Hypotheses 1 to 3 were tested using the Chi square test of independence at a 5\% level of significance. This test demonstrates the dependency (or independency) between two variables. It can be used to determine the relation of two qualitative or sequence variables that have several categories, categorical variables. The null hypothesis $\mathrm{H}_{0}$ states that the researched items are independent; an alternative Hypothesis $\mathrm{H}_{1}$ expresses their dependence. Null hypotheses were formulated as follows:

- $\quad H_{0-1}$ : The interest in doing business does not differ among students of economic and non-economic programmes.

- $\quad H_{0-2}$ : The perception of preconceptions as a barrier to starting a business does not differ among students of economic and non-economic programmes.

- $H_{0-3}$ : In terms of subjective perception of one's own business idea and knowledge of implementation, students of economic and non-economic programmes are no different.

Hypothesis 4 was tested using the Spearman correlation coefficient $r_{s}$. This test was used because the data follow a non-normal distribution and the order of values is dominant. The dependent variable is business knowledge (quantitative variable). The independent variables are the attitudes concerning entrepreneurship (ordinal variable). The null hypothesis $\mathrm{H}_{0-4}$ was formulated as follows: 


\section{- $H_{0-4}: r_{s}=0$}

There is no dependency between attitudes concerning entrepreneurship and knowledge.

Data were tested at a significance level of 5\%. The dependence of variables may be ascending or descending. Spearman's correlation coefficient $r_{s}$ takes values $[-1,1]$.

\section{RESULTS}

\section{Comparison of attitudes concerning entrepre- neurship and knowledge among students of economic and non-economic programmes}

The results of a comparison of attitudes concerning entrepreneurship and student knowledge are given in Table 3.
Variable

Max

Average

Economist $\mid$ Non-economist Economist $\mid$ Non-economist

Attitudes concerning entrepreneurship (the higher the value, the more interest / preconception / the more confidence in one's own business idea)

\begin{tabular}{|c|c|c|c|c|c|}
\hline A. Interest in doing business & 4 & 3.07 & 3.05 & 3 & 3 \\
\hline B. Preconceptions concerning conducting business & 4 & 2.84 & 2.82 & 3 & 3 \\
\hline C. Business idea and its transfer to reality & 5 & 2.89 & 2.91 & 3 & 3 \\
\hline \multicolumn{6}{|l|}{ Test questions } \\
\hline 1. Taking action to acquire a Trade Licence & 2 & 1.57 & 1.59 & 2 & 2 \\
\hline 2. Conditions for obtaining an unqualified notifiable trade & 2 & 1.44 & 1.43 & 2 & 2 \\
\hline 3. Registration to the tax office & 1 & 0.88 & 0.88 & 1 & 1 \\
\hline 4. Social insurance of an individual entrepreneur & 1 & 0.67 & 0.66 & 1 & 1 \\
\hline 5. Keeping records with an individual entrepreneur & 3 & 1.61 & 1.60 & 2 & 2 \\
\hline 6. Keeping records with a trading company & 1 & 0.77 & 0.75 & 1 & 1 \\
\hline 7. The amount of registered capital & 1 & 0.64 & 0.63 & 1 & 1 \\
\hline Total score & 11 & 8 & 7.55 & 7.58 & 8 \\
\hline
\end{tabular}

Table 3: Descriptive Statistics of Variables, 2018 (Source: Authors' Calculation)

Attitudes concerning entrepreneurship (factors A - C) among students of economic and non-economic study programmes at the College of Polytechnics Jihlava are balanced. The results show that students of both study programmes are more interested in doing business than their entrepreneurial preconceptions are (it is evidenced in average values for factors A, B). At the same time, their concerns about doing business are high (factor B). Preconceptions have been defined as business risk, self-insecurity, job security, lack of information on starting a business and managing it. The results are surprising as they show a high interest in entrepreneurship regardless of the study programme (balanced in both groups) and with a high level of concern of doing business (cf. Lima et al., 2015). Despite these preconceptions, students tend to be more into doing business. This result may also be related to students' motivation to practically oriented education, which was proven with students of the College of Polytechnics Jihlava in 2018 (Berková, Borůvková and Lízalová, 2018).

The analysis of students' knowledge of starting a business and legislative processes does not fully correspond to their attitudes. The total average score of all students $(n=104)$ from the knowledge test is 7.59 points, i.e. $69.1 \%$ success rate. In the view of the interest in doing business, students were the least successful in the question of keeping records with an individual entrepreneur. The success rate of economic study programmes was $54 \%$ and $53 \%$ in non-economic study programmes. Although students have shown interest in doing business, they are not fully aware of the real situation in the area of taxes and accounting and other legislative processes. Therefore, the researchers do not consider the test results to be positive. It will be necessary to strengthen students' knowledge and practical preparation for conducting business in the area of taxes and accounting. A comparison of the results between economic and non-economic study programmes points to the compliance (according to the median). According to average values, the results are better for students in non-economic programmes, but the difference is very small. Despite these consistent results, it should be noted that students of economic and non-economic programmes may be motivated in the education area differently. This means that they have different expectations, needs and requirements from tertiary studies. Applied Informatics students are more motivated compared to the students in the Finance and Management field. Their demands on education are higher. Their desire of knowledge is higher, they are more inquisitive. If they do not get deeper knowledge from teachers, they are demotivated. In contrast, students in the economic field are more indifferent to education. This means that they have lower ambitions for new deeper knowledge. Motivation can be a factor that affects students' knowledge even at the expense of further self-education (Berková, Borůvková and Lízalová, 2018).

The article does not deal more with the differences among students by the year of their studies because of the small size of the sample.

\section{Differences in students' attitudes concerning entrepreneurship in terms of interest, precon- ditions and subjective evaluation of one's own idea and its implementation}

Table 4 shows the results of testing the null hypotheses from $\mathrm{H}_{0-1}$ to $\mathrm{H}_{0-3}$, using the Chi square independence test. Data were analyzed at a significance level of 5\%. 


\begin{tabular}{c|c|c|c}
\hline Null hypotesis & Critical value & Test statistics & $\boldsymbol{p}$-value \\
\hline $\mathrm{H}_{0-1}$ & 7.815 & 4.527 & 0.209 \\
\hline $\mathrm{H}_{0-2}$ & 7.815 & 2.032 & 0.566 \\
\hline $\mathrm{H}_{0-3}$ & 9.488 & 3.122 & 0.538 \\
\hline
\end{tabular}

Table 4: $p$-values Chi square test - difference between economic and non-economic study programme, 2018 (Source: Authors' Calculation)

The null hypotheses $\mathrm{H}_{0-1}, \mathrm{H}_{0-2}, \mathrm{H}_{0-3}$ can't be rejected on the level of significance $5 \%$. This means that there are no significant differences between students of economic and non-economic study programmes in the field of entrepreneurship, business preconceptions. Also, there were no significant differences between groups in having their own business idea and knowledge of its implementation. Thus, it can be stated that for $n=104$ students of economic and non-economic programmes, they behave in the same way. This can also be compared to the results of the average values of the factors under research (Table 3 ) in which the differences between groups are small. This result is not in harmony with researchers' expectations. Table 5 shows the results of testing the null hypothesis $\mathrm{H}_{0-4}$ using the Spearman correlation coefficient (correlation matrix).

\begin{tabular}{lccccc} 
& Knowledge & Interest in business & Preconceptions & Own idea \\
\hline Knowledge & 1.000 & 0.125 & -0.116 & 0.018 \\
\hline Interest in business & 0.125 & 1.000 & -0.374 & 0.458 \\
\hline Preconceptions & -0.116 & -0.374 & 1.000 & -0.296 \\
\hline Own idea & 0.018 & 0.458 & -0.296 & 1.000 \\
\hline
\end{tabular}

Table 5: Spearman's Correlation Coefficient, 2018 (Source: Authors' Calculation)

At the 5\% level of significance, there was no proven correlation between entrepreneurial interest and knowledge $(p=0.205)$, preconceptions concerning entrepreneurship and knowledge $(p=0.239)$ and having one's own business idea and knowledge $(p=0.858)$. At the same time, the values of Spearman's correlation coefficient, which do not exceed value 0.4 , prove this fact too. At the $5 \%$ level of significance, the null hypothesis $\mathrm{H}_{0-4}$ isn't rejected.

Furthermore, the frequency of students' representation in individual variations of Part C - Business Idea and its Implementation was analysed. The data are shown in Table 6 .

\begin{tabular}{|c|c|c|c|c|}
\hline \multirow[b]{2}{*}{ Variations } & \multicolumn{2}{|c|}{ Economic programme } & \multicolumn{2}{|c|}{ Non-economic programme } \\
\hline & $\begin{array}{l}\text { Absolute } \\
\text { frequency }\end{array}$ & $\begin{array}{c}\text { Relative } \\
\text { frequency \% }\end{array}$ & $\begin{array}{l}\text { Absolute } \\
\text { frequency }\end{array}$ & $\begin{array}{c}\text { Relative } \\
\text { frequency \% }\end{array}$ \\
\hline I have an idea and I don't know how to implement it. & 7 & 11.29 & 9 & 21.43 \\
\hline $\begin{array}{l}\text { I have an idea, but I'm afraid it's not good enough (so I'm not talking } \\
\text { about it). }\end{array}$ & 19 & 30.65 & 12 & 28.57 \\
\hline $\begin{array}{l}\text { I have a business idea and I know exactly how to get started, what it } \\
\text { takes. }\end{array}$ & 5 & 8.06 & 4 & 9.52 \\
\hline $\begin{array}{l}\text { I have no business idea and at the same time, I do not know how to get } \\
\text { started and how it works. }\end{array}$ & 12 & 19.35 & 9 & 21.43 \\
\hline I have no business idea, but I know how to start a business. & 19 & 30.65 & 8 & 19.05 \\
\hline
\end{tabular}

Table 6: Business Idea and its Implementation - Frequency 2018 (Source: Authors' Calculation)

For the students of economic and non-economic programmes, these similar behaviour traits can be found (in terms of the most frequent representation in the answers):

1. Have their own business idea but do not know how to start the business - they do not have the relevant knowledge (30.65\% for economic programmes and $28.57 \%$ for noneconomic programmes), or

2. They have no idea but have all the knowledge about starting a business (30.65\% for economic programmes and $19.05 \%$ for non-economic programmes).

In the group of students of economic programmes, $50 \%$ of students have their own business idea. The researchers consider this result to be positive and therefore they see the potential for further development concerning entrepreneurship.

However, there is a bigger problem with the knowledge of entrepreneurship and starting business in the non-economic study programmes. $21.43 \%$ of students of non-economic programmes admit that they lack this knowledge. At the same time, the same representation of students has a business idea and does not know how to implement it. They are interested in doing business, but they are afraid of starting and conducting business because they lack information. Therefore, it will be desirable to strengthen students' motivation through new platforms and practical training methods. Training that will focus on entrepreneurship education, such as start-ups.

\section{DISCUSSION}

The research focused on students of professionally oriented College of Polytechnics Jihlava did not confirm the hypothesis that there are differences in the attitudes and knowledge of entrepreneurship among students of economic and noneconomic study programmes. However, it has brought several interesting findings relevant to the future direction of the college education. It should be noted that the results are indicative as the sample of respondents includes only part of the students of the College of Polytechnics Jihlava. Considering that the number of students at the time of the research was approximately 2,000 , there is a certain limit 
to the research in this respect. 104 students were involved in the project, and all of them were also involved in the research that is why the sample can be considered credible, bringing relevant results. It would also be interesting to compare differences in interest in entrepreneurship and knowledge among students in different years of bachelor's studies. Students in different years of studies have different knowledge and practical skills with regard to their previous school or other experience. However, the results of this indepth analysis did not produce significant results with an impact on the recommendations for education and economic practice. The lower sample of students is a limitation in this respect. Therefore, a comprehensive analysis for all years of bachelor's studies published in the article was conducted.

The results of the research are inconsistent with the empirical study (Lima et al., 2015). The authors of this study found a negative correlation of interest in entrepreneurship with higher education. These relations were not proven on a sample of students of the College of Polytechnics Jihlava. There are no differences in the interest in entrepreneurship, business preconceptions, and worries about this activity among students of different study programmes. Significant differences between student groups have not been proven even in the area of having their own business ideas and knowing how to start a business. However, this discrepancy may be due to the lower sample - the number of 104 students were involved in the entrepreneurship education project during 2018. Research is, therefore, the initial research as well as a stimulus for its expansion.

Worries about doing business are high among students of both programmes. Although they have the desire to do business and have their own business idea, they are afraid of starting their activities and they rather concentrate on studying at college. Parker (2004) explored the relationship between students' personal traits to entrepreneurship (willingness to risk, the need for success, the desire for autonomy, etc.) and the success of graduating from a college. He found negative relations among variables, which corresponds to the results of this research. Polytechnic College students have high preconceptions about doing business, at the same time they are interested in doing business, but their worries about starting a business are so big that they do not want to start it and thus they focus on their college studies. Cho (2017) recommends improving the quality of education through entrepreneurial education programmes for reconciling entrepreneurship with completing a university degree programme. Therefore, the possibility of doing their own business at the university, for example in the form of startups will be provided to students. Practical training is very motivating for students. Berková, Borůvková and Lízalová (2018) proved that in general context, the practicality and interactive form of teaching for students of non-economic programmes (technical fields) is more motivating than for students of economic programmes in the conditions of the College of Polytechnics Jihlava. Therefore, the creation of educational platforms for the development of entrepreneurship education, which is practical, will help students to focus on business, at the same time graduate from a college and, last but not least, develop the business potential of some Czech cities and regions. This can be gradually achieved already at college through experience-based learning (Lee et al., 2018). Although traditional methods are important and have a place in education, they are not dominant for entrepreneurship education. Von Graevenitz, Harhoff and Weber (2010) also positively perceive entrepreneurship education. They are of the opinion that both students and society can benefit from it. Such a combination of theory and practice in support of students' business plans has already been recommended by Fayolle, Gailly and Lassas-Clerc (2006). Entrepreneurship education has become a phenomenon that is important in both - in education as well as in practice (Anderson and Jack, 2008).

In particular, entrepreneurship education must provide students with general business knowledge, awareness of financial analysis, planning, pricing strategies, human resources management (Block and Stumpf, 1992). Knowledge may or may not be essential for starting a business. This research has not proven a correlation between students' attitudes concerning entrepreneurship and their knowledge of starting a business from a tax perspective and setting up a business. The results show that entrepreneurial potential can be seen in students of different study programmes. However, it is important to build an effective platform and content for entrepreneurship education (cf. Fayolle, Gailly and LassasClerc, 2006)

\section{CONCLUSION}

The position and importance of entrepreneurship education are steadily increasing and becoming an important part of the implementation of higher education programmes in the national and international context. Research conducted at the end of 2018 among students of the College of Polytechnics Jihlava in the Czech Republic shows that students of various study programmes are eager to do business, have their own entrepreneurial ideas, but are afraid of starting their activities. There were 104 students who were involved in a project supporting starting their own business during the time studying at the college. It is a pilot project, its sustainability is guaranteed and its second year will be implemented in 2019. Students need leadership in the form of new platforms to ensure the development of entrepreneurship education at the college, regardless of the focus of study programmes. This is the right way to promote entrepreneurship in society by investing in young people's development.

\section{ACKNOWLEDGEMENT}

This research was supported by the College of Polytechnics, Jihlava, Czech under Grant No. 1170/4/1817 "Starting for the development of students' entrepreneurial potential of College of Polytechnics Jihlava" and it is part of a project of Faculty of Finance and Accounting realized with help of institutional support VŠE IP100040. 
Anderson, A.R. and Jack, S.L. (2008) 'Role typologies for enterprising education: the professional artisan?', Journal of Small Business and Enterprise Development, Vol. 15, No. 2, pp. 259-273. https:// doi.org/10.1108/14626000810871664

Block, Z. and Stumpf, A. (1992) 'Entrepreneurship education research: experience and challenge'. In: Sexton, D., Kasarada, J. (eds.) The State of the Art of Entrepreneurship, pp. 17-42.

Berková, K., Borůvková, J. and Lízalová, L. (2018) 'Motivation of Students of Economic and Technical Fields as a Tool of Competitiveness of Universities and Colleges: Empirical Study', Journal on Efficiency and Responsibility in Education and Science, Vol. 11, No. 4, pp. 72-77. https://doi.org/10.7160/ eriesj.2018.110401

Buenstorf, G., Nielsen, K. and Timmermans, B. (2017) 'Steve Jobs or No Jobs? Entrepreneurial activity and performance among Danish college dropouts and graduates', Small Business Economics, Vol. 48, No. 1, pp. 179-197. https:/dx.doi.org/10.1007/s11187-016$\underline{9774-1}$

Chen, L. (2013) 'IT entrepreneurial intention among college students: An empirical study', Journal of Information Systems Education, Vol. 24, No. 3,pp. 233-242. http://dx.doi.org/10.18000/ijisac.50150

Cho, Y.J. (2017) 'A study on the influence of University entrepreneurial education service quality of entrepreneurial intention: focused on the mediating effects of satisfaction with entrepreneurial education', Asia-Pacific Journal of Business Venturing and Entrepreneurship, Vol. 12, No. 2, pp. 95-103.

College of Polytechnics Jihlava (2018) Výroční zpráva o činnosti Vysoké školy polytechnické Jihlava pro rok 2018 [Annual Report on VŠPJ Activities, 2018], [Online], Available: https://www.vspj.cz/skola/ uredni-deska/vyrocni-zpravy-o-hospodareni [4 Oct 2019].

Cromie, S. (2000) 'Assessing entrepreneurial inclinations: Some approaches and empirical evidence', European journal of work and organizational psychology, Vol. 9, No. 1, pp. 7-30. https://doi. org/10.1080/135943200398030

Decker, W.H., Calo, T.J. and Weer, C.H. (2012) 'Affiliation motivation and interest in entrepreneurial careers', Journal of Managerial Psychology, Vol. 27, No. 3, pp. 302-320. https://doi. org/10.1108/02683941211205835

Fayolle, A., Gailly, B. and Lassas-Clerc, N. (2006) 'Assessing the impact of entrepreneurship education programmes: a new methodology', Journal of European industrial training, Vol. 30, No. 9, pp. 701720. https://doi.org/10.1108/03090590610715022

Fiet, J.O. (2001) 'The pedagogical side of entrepreneurship theory', Journal of business venturing, Vol. 16, No. 2, pp. 101-117. https:// dx.doi.org/10.1016/S0883-9026(99)00042-7

Gartner, W.B. (1988) 'Who is an entrepreneur? is the wrong question', American journal of small business, Vol. 12, No. 4, pp. 11-32. https://doi.org/10.1177/104225878801200401

Hatten, T.S. and Ruhland, S. K. (1995) 'Student attitude toward entrepreneurship as affected by participation in an SBI program', Journal of Education for Business, Vol. 70, No. 4, pp. 224-227. https://doi.org/10.1080/08832323.1995.10117754

Ireland, R.D., Hitt, M.A., Camp, S.M. and Sexton, D.L. (2001) 'Integrating entrepreneurship and strategic management actions to create firm wealth', Academy of Management Perspectives, Vol. 15, No. 1, pp. 49-63. https://doi.org/10.5465/ame.2001.4251393
Kreiser, P.M., Marino, L.D. and Weaver, K.M. (2002) 'Assessing the psychometric properties of the entrepreneurial orientation scale: A multi-country analysis', Entrepreneurship theory and practice, Vol. 26, No. 4, pp. 71-93. https://doi. org/10.1177/104225870202600405

Lee, S.T., Lee, H.K., Ki, H.S. and Gim, G.Y. (2018) 'An Influence on Online Entrepreneurship Education Platform Utilization and Selfdeterministic to College Students' Entrepreneurial Intention', International Conference on Computer and Information Science. Springer, Cham, pp. 189-211. https://doi.org/10.1007/978-3-31998693-7 13

Lima, E., Lopes, R. M., Nassif, V. and da Silva, D. (2015) 'Opportunities to improve entrepreneurship education: Contributions considering Brazilian challenges', Journal of Small Business Management, Vol. 53, No. 4, pp. 1033-1051. https://doi.org/10.1111/jsbm.12110

McCrae, R.R. and John, O.P. (1992) 'An introduction to the five-factor model and its applications', Journal of personality, Vol. 60, No. 2, pp. 175-215. http://dx.doi.org/10.1111/j.1467-6494.1992. $\underline{\mathrm{tb} 00970 . \mathrm{x}}$

Miner, J.B. (2000) 'Testing a psychological typology of entrepreneurship using business founders', Journal of Applied Behavioral Science, Vol. 36 No. 1, pp. 43-69. https://doi. org $/ 10.1177 / 0021886300361003$

Ministry of Industry and Trade (2017) Zpráva o vývoji malého a středního podnikáni a jeho podpoře $v$ roce 2017 [Report on Small and Medium Enterprises Development and Support in 2017], [Online], Available: https://www.mpo.cz/assets/ cz/podnikani/male-a-stredni-podnikani/studie-a-strategickedokumenty/2018/10/Zprava_MSP_2017.pdf [4 Oct 2019].

Murugesan, R. and Dominic, P.D.D. (2012) 'A study on association between personality constructs and entrepreneurial attitudes', International Journal of Business Excellence, Vol. 5, No. 4, pp. 378-394. https://dx.doi.org/10.1504/IJBEX.2012.047905

Neck, C.P., Neck, H.M., Manz, C.C. and Godwin, J. (1999) 'I think I can; I think I can': a self-leadership perspective toward enhancing entrepreneur thought patterns, self-efficacy, and performance', Journal of Managerial Psychology, Vol. 14, No. 6, pp. 477-501. https://doi.org/10.1108/02683949910287912

Parker, S.C. (2004) The economics of self-employment and entrepreneurship. Cambridge: University Press.

Rauch, A. and Frese, M. (2000) 'Psychological approaches to entrepreneurial success: a general model and an overview of findings', in Cooper, C.L. and Robertson, I.T. (Eds.), International Review of Industrial and Organizational Psychology, pp. 101141. Chichester: Wiley.

Rauch, A. and Frese, M. (2007) 'Let's put the person back into entrepreneurship research: A meta-analysis on the relationship between business owners' personality traits, business creation, and success', European Journal of work and organizational psychology, Vol. 16, No. 4, pp. 353-385. https://doi. org/10.1080/13594320701595438

Ronstadt, R. (1985) 'The educated entrepreneurs: A new era of entrepreneurial education is beginning', American journal of small business, Vol. 10, No. 1, pp. 7-23. https://doi. org/10.1177/104225878501000102 
Schumpeter, J.A. (1934) The theory of economic development. New York: Harvard.

Simpeh, K.N. (2011) 'Entrepreneurship theories and Empirical research: a summary review of the literature', European Journal of Business and Management, Vol. 3, No. 6, pp. 1-8.

Stewart, W.H. and Roth, P.L. (2007) 'A meta-analysis of achievement motivation differences between entrepreneurs and managers', Journal of Small Business Management, Vol. 45, No. 4, pp. 401-421. https://doi.org/10.1111/j.1540-627X.2007.00220.x

UNCTAD Secretariat (2011) 'Entrepreneurship Education, Innovation and Capacity-Building in Developing Countries', United Nations Conference on Trade and Development (UNCTAD), Geneva, pp. 1-21. van Eeden, S., Louw, L. and Venter, D. (2005) 'Entrepreneural traits of undergraduate Commerce students: a three-country comparison', Management Dynamics: Journal of the Southern African Institute for Management Scientists, Vol. 14, No. 3, pp. 26-43.

von Graevenitz, G., D. Harhoff, and Weber, R. (2010) 'The Effects of Entrepreneurship Education', Journal of Economic Behavior and Organization, Vol. 76, No. 1, pp. 90-112. https://doi. org/10.1016/j.jebo.2010.02.015

Zhang, S. (2014) 'Successful Internet Entrepreneurs Don't Have To Be College Dropouts: A Model for Nurturing College Students to Become Successful Internet Entrepreneurs', International Journal of Information and Communication Technology Education (IJICTE), Vol. 10, No. 4, pp. 53-69. https://dx.doi. org/10.4018/ijicte.2014100105 